\title{
Mapping the Internal and External Environments in Empowering Semanggi Batik Craftsmen in Surabaya
}

\section{Pemetaan Lingkungan Internal - Eksternal Dalam Upaya Pemberdayaan Pengrajin Batik Semanggi Kota Surabaya}

\author{
Susi Hardjati*, Ananta Prathama, Kalvin Edo Wahyudi \\ Universitas Pembangunan Nasional "Veteran" Jawa Timur
}

Batik Semanggi is one of the typical batiks in Surabaya which has economic value for the community. However, the competitiveness of the clover batik business is relatively low. This study aims to identify the internal environmental conditions (strengths-weaknesses) and external (opportunities-threats) of the clover batik craftsmen as the basis for formulating a strategy to increase competitiveness. The study used a qualitative approach with data collection techniques focus group discussions (FGD), semi-structured interviews, observation and document collection. Informants were determined using a purposive method. The data analysis uses interactive models and SWOT analysis. The results showed several strengths that can encourage the floating of clover batik, namely the ability to make a capable batik, iconic distinctive motifs and organic batik technology. The

OPEN ACCESS

ISSN 2527-9246 (online) ISSN 2338-445X (print)

Edited by:

Sri Juni Woro Astuti

Reviewed by:

Sri Maryuni and Gede Sandiasa

*Correspondence: Susi Hardjati

susi_hardjati.adneg@upnjatim.ac.id

Published: 1 Maret 2020

Citation:

Hardjati S, Prathama A and Wahyudi KE (2020) Mapping the Internal and External Environments in Empowering Semanggi Batik

Craftsmen in Surabaya.

JKMP (Jurnal Kebijakan dan

Manajemen Publik). 8:1.

doi: 10.21070/jkmp.v8i1.725 opportunities that arise, namely export opportunities, support of the city government, support of other elements of society, and online marketing opportunities. While weaknesses include the number of craftsmen, low online marketing capabilities, motives not yet registered as intellectual property rights, limited production, and marketing volumes, traditional tools, and low capital. The threat that arises namely, the emergence of other motifs as a competitor batik, and batik printing production that offers cheaper prices with a larger production scale. The map of strengths and weaknesses and threats above are very useful as a material for formulating strategies in empowering clover batik craftsmen.

Keywords: Craftsman Empowerment, Batik Semanggi, SWOT

\section{PENDAHULUAN}

Batik adalah produk budaya yang menjadi salah satu identitas Bangsa Indonesia yang telah diwariskan lintas generasi. Bahkan, eksistensi batik telah diakiui oleh masyarakat internasional melalui pengakuan dari United Nations Educational, Scientific and Cultural Organization (UNESCO) pada tanggal 2 Oktober 2009. UNESCO menetapkan batik sebagai salah satu warisan budaya Indonesia yang layak untuk dimasukkan dalam Representative List of the Intangible Cultural Heritage of Humanity, artinya bahwa batik sebagai warisan budaya leluhur 
bangsa Indonesia diharapkan batik dapat menjadi roda penggerak perekonomian dan mengangkat kesejahteraan masyarakat khususnya pengrajin batik (Sudantoko, 2011).

Pengakuan UNESCO terhadap batik menyebabkan nilai ekonomi dari usaha batik mengalami peningkatan. termasuk di Wilayah Surabaya. Di Kota Surabaya terdapat beberapa batik dengan corak yang khas, salah satunya adalah Batik Semanggi yang diproduksi di Kelurahan Sememi Kecamatan Benowo Kota Surabaya. Motif batik semanggi terinspirasi dari daun semanggi yang banyak dijumpai di Kelurahann Sememi Kecamatan Benowo dan banyak diolah menjadi kuliner khas Surabaya yaitu pecel semanggi. Dengan demikian, Batik semanggi telah "ikon" di daerah tersebut. Selain itu, batik semanggi juga memiliki filofsofi yaitu "semangat tinggi”.

Pada awalnya, kerajinan batik di Sememi ini didirikan oleh ibu-ibu PKK pada tahun 2015. Para pembatiknya merupakan ibu-ibu warga RW 01 Jalan Sememi Jaya Gang 8 Kelurahan Sememi Kecamatan Benowo. Kegiatan membatik ini ditujukan untuk ibu-ibu dalam mendukung ekonomi keluarga. Melalui kegiatan membatik ini, proses pemberdayaan untuk ibu-ibu PKK selaku pengrajin batik dapat meningkatkan ekonomi di Kelurahan Sememi Kecamatan Benowo.

Hasil riset pendahuluan menunjukkan bahwa ada beberapa problem dalam produksi batik semanggi di Kelurahan Sememi Kecamatan Benowo Surabaya, yaitu sebagai berikut.

1. Sistem produksi batik semanggi di Kelurahan Sememi Kecamatan Benowo Surabaya didasarkan atas adanya pesanan, dan jika tidak ada pesanan maka mereka tidak berproduksi. Fakta ini menunjukkan bahwa produksi batik semanggi tidak sustainable.

2. Produksi batik semanggi sempat vakum selama 3 tahun, hal ini dikarenakan system tata kelola yang diselenggarakan belum professional.

Berdasarkan hasil riset pendahuluan di atas, dapat disimpulkan bahwa perlu ada perhatian serius agar masyarakat pengrajin dapat lebih berdaya saing. Untuk itu diperlukan formulasi strategi pemberdayaan yang tepat agar produksi batik semanggi menjadi baik dengan menggunakan formulasi strategi yang handal selalu didahului dengan pemetaan kondisi lingkungan internal dan eksternal. Secara teoritis, aspek lingkungan dibagi menjadi lingkungan internal dan lingkungan eksternal. Lingkungan internal dianalisis untuk memetakan kekuatan (strength) dan kelemahan (weakness) dari institusi, dalam hal ini kelompok masyarakat pengrajin batik semanggi. Sedangkan lingkungan eksternal dianalisis untuk memetakan peluang (opportunity) dan tantangan (threats) dalam produksi batik semanggi. Inilah yang menjadi fokus penelitian ini, yaitu menganalisis lingkungan internal dan eksternal untuk mencari kekuatan, kelemahan, peluang dan tantangan (SWOT) dalam produksi batik semanggi. Inilah yang menjadi fokus dan tujuan dari penelitian ini.

Terdapat beberapa penelitian dengan tema yang serupa namun di dengan lokasi yang berbeda, seperti penelitian Pamungkas (2010) dengan judul "Pemberdayaan Masyarakat Melalui Usaha Industri Kecil Batik Semarang16 di Bukit Kencana Jaya Tembalang Semarang. Hasil penelitian tersebut menunjukkan bahwa pemberdayaan masyarakat di objek penelitian tersebut telah berjalan baik dari sisi perencanaan, pelaksanaan dan evaluasi, bahkan pemberdayaan masyarakat melalui industry batik tersebut telah berdapakan positif bagi perekonomian masyarakat.

Penelitian lainnya dengan tema serupa dapat dilihat dari penelitian Juardi, dkk (2014) yang berjudul "Pengembangan Usaha Indisti Kecil Melalui Pemberdayaan Masyarakat di Kecamatan Tering Kabupaten Kutai Barat". Hasil penelitian ini menunjukkan bahwa peran pemertintah daerah dalam pemberdayaan yang dilakukan untuk masyarakat telah memberikan dampak yang positif khususnya dalam aspek ekonomi dan social. Strategi pemberdayaan dapat dilakuakan dengan bantuan sarana produksi, pemberian bantuan modal, dan penataan kelembagaan Juardi and Djumadi (2014).

Penelitian lainnya dengan tema serupa dapat dilihat dari penelitian Mayangsari (2015) yang berjudul "Dampak Pemberdayaan Pengrajin Batik oleh Diskoperindag dan ESDM terhadap Peningkatan Kesejahteraan UMKM Batik Jetis Sidoarjo". Hasil penelitian ini menunjukkan bahwa peran pemerintah Kabupaten Sidoarjo (dalam hal ini Diskoperindag dan ESDM telah berjalan optimal dan mampu meningkatkan kemampuan pengrajin batik, baik dalam penguasaan teknologi membatik maupun pencarian akses permodalan dan pemasaran. Dengan 
capaian tersebut, program pemberdayaan telah berdampak positif dalam peningkatan kesejahteraan masyarakat.

Dari penelitian terdahulu di atas, dapat disimpulkan bahwa peran pemerintah dalam memberdayakan usaha kecil masyarakat memang sangat dibutuhkan. Peran nyata pemerintah telah terbukti mampu meningkatkan ekonomi masyarakat menjadi lebih baik. Penelitian-penelitian tersebut dapat dijadikan referensi dan gambaran untuk konstruksi penelitian ini yang berfokus pada strategi pemberdayaan pengrajin batik semanggi kelurahan sememi kecamatan Benowo Kota Surabaya. Bagian pertama dari penelitian ini adalah mengidentifikasi lingkungan internal dan eksternal dari pengrajin tersebut sebagai acuan untuk merumuskan strategi pemberdayaan di bagian kedua.

\section{Pemberdayaan}

Kata pemberdayaan berasal dari kata "daya" yang mendapatkan awalan "ber" menjadi kata "berdaya" yang berarti mempunyai daya. Pada hakekatnya pemberdayaan bersentuhan dengan konsep mengenai kekuasaan (Suharto, 2005). Lebih lanjut dikemukakan pemberdayaan menunjuk pada upaya untuk membangun kemampuan orang, khususnya kelompok rentan dan lemah melalui cara membangkitkan kesadaran mengenai potensi dirinya sehingga mereka memiliki kekuatan atau kemampuan dalam (a) memenuhi kebutuhan hidup yang paling dasar sehingga mereka memiliki kebebasan (freedom), dalam arti bukan saja bebas menyampaikan pendapat, melainkan bebas dari kelaparan, bebas dari kebodohan, bebas dari kesakitan; (b) mengembangkan sumber-sumber produktif sehingga menjadikan mereka dapat meningkatkan pendapatannya serta memperoleh barang dan jasa yang mereka perlukan dengan mudah; (c) berpartisipasi dalam kegiatan pembangunan dan keputusan-keputusan yang mempengaruhi mereka menjadi masyarakat mandiri.

Mardikanto (2012) mengemukakan bahwa pemberdayaan memiliki arti perbaikan kualitas hidup atau meningkatkan kesejahteraan setiap individu dan masyaraka, antara lain: (1) Perbaikan ekonomi, terutama terpenuhinya kebutuhan pangan, (2) Perbaikan kesejahteraan sosial yang berhubungan dengan perbaikan bidamg pendidikan dan kesehatan, (3) Kemerdekaan dari segala bentuk penindasan, (4) Terjaminnya keamanan, (5) Terjaminnya hak asasi manusia yang bebas dari rasa takut dan kekhawatiran.

Menurut Suharto (2005) pemberdayaan dapat dilakukan melalui tiga pendekatan yang meliputi: 1) Pendekatan mikro, pemberdayaan dilakukan terhadap individu melalui bimbingan, konseling, stress managment, crisis intervention. Tujuannya adalah membimbing dan melatih individu dalam menjalankan tugas-tugas kehidupannya. Model pendekatan ini biasanya disebut pendekatan yang berpusat pada tugas (task centered approach). 2) Pendekatan mezzo. Pemberdayaan yang dilakukan kepada kelompok masyarakat atau komunitas. Model yang digunakan melalui pendidikan, pelatihan serta dinamika kelompok. hal ini bertujuan untuk meningkatkan kesadaran, pengetahuan, dan ketrampilan serta sikap-sikap kelompok masyarakat agar mereka memiliki kemampuan dalam memecahkan permasalahan yang dihadapi. 3) Pendekatan makro, Pendekatan ini disebut juga strategi sistem besar (large system strategy), Pemberdayaan ditujukan pada sistem lingkungan dan masyarakat yang lebih luas. Seperti misalnya dalam hal perumusan kebijakan, perencanaan sosial, kampanye, aksi sosial, lobi, pengorganisasian dan pengembangan masyarakat, merupakan beberapa strategi dalam pendekatan ini.

Strategi pemberdayaan yang akan diterapkan dalam penelitian ini menggunakan teknik SWOT Analysis. SWOT analysis adalah salah satu teknik untuk memformulasikan strategi. SWOT analysis terdiri atas analisa situasi lingkungan internal dan ekternal dari entitas yang akan diteliti. Lingkungan internal mengacu pada pencarian kekuatan dan kelemahan, sedangkan lingkungan eksternal mengacu pada analisis peluang dan tantangan.

\section{METODE PENELITIAN}

Jenis penelitian ini adalah deskriptif kualitatif, yaitu suatu metode yang digunakan untuk menggambarkan dan menganalisis mengenai status dan obyek tertentu, kondisi tertentu, sistem 
pemikiran atau suatu kejadian tertentu pada saat sekarang. Menurut Moleong (2012), penelitian kualitatif merupakan penelitian yang bertujuan untuk memahami, membuat deskripsi atau gambaran secara sistematis, faktual dan akurat mengenai fakta-fakta, sifat-sifat serta hubungan antara fenomena yang diteliti. Penelitian ini menerapkan beberapa teknik pengumpulan data, yaitu sebagai berikut.

\section{Wawancara}

Wawancara merupakan metode pengumpulan keterangan atau data penelitian yang dilakukan dengan cara tanya jawab secara langsung kepada informan guna untuk memperoleh informasi langsung dari sumber data. Adapun informan dalam penelitian ini kami tentukan melalui metode purposive sampling adalah sebagai berikut:Lurah Sememi Kecamatan Benowo, Kepala Dinas Koperasi dan UMKM Kota Surabaya, Ketua dan Pengurus Kelompok Pengrajin Batik Semanggi Kelurahan Sememi, Anggota Pengrajin Batik Semanggi Kelurahan Sememi

\section{Observasi}

Observasi merupakan pengamatan yang jelas dan rinci terhadap gejala-gejala yang diteliti. Kegiatan observasi dalam penelitian ini adalah guna memperoleh keterangan dan informasi mengenai hal-hal yang diteliti serta untuk mengetahui relevansi antara jawaban atau informasi dari informan dengan kenyataan yang terjadi di lapangan. Pengamatan yang dilakukan adalah terkait motif dan kegiatan pengrajin dalam membatik.

\section{Dokumentasi}

Dokumentasi dalam pengumpulan data ini dimaksudkan sebagai metode pengumpulan data dengan cara mempelajari dan mencatat bagian-bagian yang dianggap penting dari berbagai risalah resmi yang terdapat di lokasi penelitian.

\section{Focus Group Discussion (FGD)}

Focus Group Discussion (FGD) merupakan teknik pengumpulan data yang umumnya dilakukan pada penelitian kualitatif. Hal ini bertujuan menemukan makna sebuah tema menurut pemahaman sebuah kelompok. FGD dalam penelitian ini digunakan sebagai alat pengumpulan data penelitian yang bertujuan untuk mendapatkan data dan gambaran tentang pemberdayaan yang dilakukan di pengrajin batik.

Teknik analisis data dalam penelitian ini menggunakan teknik analiis data model interaksi dari Miles dan Huberman. Untuk mencari Strenghts, Weakness, Opportunities dan Threaths (SWOT). menurut Miles dan Huberman, setidaknya ada 3 komponen utama dalam analisis data, yaitu data reduction, data display, dan conclusion drawing/verification. Pola hubungan antar ketiga komponen tersebut cenderung bersifat interaktif Miles and Huberman (1994) .

\section{HASIL DAN PEMBAHASAN}

\section{Analisis SWOT}

Analisis SWOT adalah adalah salah satu teknik formulasi rencana strategik yang sangat dikenal oleh kalangan akademisi. Analisis SWOT terdiri atas dua tahap yang dilakukan secara berkesinambungan. Tahap pertama adalah analisis lingkungan internal (untuk memetakan faktor-faktor apa yang menjadi kekuatan dan kelemahan yang) dan lingkungan eksternal (faktor apa yang menjadi peluang dan ancaman) David (2014). Kekuatan dan peluang, akan bernilai positif karena dapat mendorong upaya pemberdayaan guna meningkatkan daya saing pengrajin batik semanggi. Sebalinya, kelemahan dan ancaman akan bernilai negatif karena akan menghambat pemberdayaan dan daya saing pengrajin batik semanggi. Adapu tahap kedua adalah tahap formulasi strategi berdasarkan kekuatan-peluang dan kelemahan ancaman yang telah diformulasikan. Adapaun fokus penelitian ini adalah pada tahap yang pertama. Seperti 
yang dijelaskan sebelumnya bahwa fokus penelitian ini adalah untuk memetakan faktor-faktor apa yang menjadi kekuatan-kelemahan maupun yang menjadi peluang-ancaman (StrengthWeakness dan Opportunity-Threat/SWOT). Adapun peta SWOT sebagaimana di maksud diuraikan di bawah ini.

\section{Analisis Internal}

Analisis internal dilakukan untuk menggali data dan informasi terkait kekuatan dan kelemahan dari kelompok pengrajin batik semanggi. Kekuatan akan bernilai positif (pendorong) bagi peningkatan daya saing produk batik semanggi, sementara kelemahan akan menjadi nilai negatif (penghambat) dalam peningkatan daya saing produk batik semanggi. Adapun aspek-aspek yan menjadi kekuatan dan kelemahan pengrajin batik semanggi diuraikan di bawah ini.

\section{Kekuatan}

1. kualitas SDM dalam hal ini kemampuan membatik cukup mumpuni. Kemampuan ini didapat oleh para pengrajin dari beberapa pelatihan yang mereka ikuti. Hasil pelatihan itu kemudian dikembangkan secara mandiri oleh para pengrajin. Sehingga kemampuan ini makin meningkat dan merata. Kemampuan membatik ini mencakup kemampuan membuat desain/motif, mencanting, mengecap, dan melorod lilin/malam dari kain batik. Secara umum kemampuan ini dapat dinilai baik, sehingga dapat dimasukkan ke dalam aspek kekuatan.

2. Terdapat manajemen/tata kelola yang cukup baik diterapkan dalam produksi batik. Para pengrajin telam menerapkan sistem pembagian tugas yang sederhana, namun mumpuni. Pembagian tugas ini disesuaikan dengan kemampuan yang dimiliki oleh masing-masing anggota. Pembagian tugas tersebut dilakukan agar produksi berjalan makin efisien. Dengan demikian, manajemen tersebut dapat dikelompokkan menjadi kekuatan.

3. Motif khas yang ikonik membuat batik semanggi punya ciri khas. Motif daun semanggi merupakan motif khas yang terinspirasi dari tanaman semanggi yang banyak tumbuh dan diolah menjadi aneka makanan di kecamatan Benowo. Motif semanggi ini tidak dapat dijumpai di daerah lain, sehingga dapat diklaim sebagai motif khas kelurahan sememi Kecamatan Benowo. Motif yang bersifat khas ini menjadikan batik semanggi memiliki daya tarik yang unik, dan menjadi kekuatan tersendiri untuk bersaing.

4. Telah menerapkan teknologi batik organik/alami yang bernilai tinggi. Kemampuan mambatik para pengrajin makin bertambah dengan dikuasainya teknologi batik dengan pewarnaan organik

5. (bukan kimia). Tentu ini akan menjadi kekuatan dalam bersaing karena nilai batik organik tentu lebih tinggi dibandingkan batik non-organik.

\section{Kelemahan}

1. Kuantitas SDM yang sangat terbatas. Pengrajin batik semanggi awalnya berjumlah 25 orang, akan tetapi terus menurun menjadi berjumlah 15 orang. Dengan jumlah tersebut, seringkali pengrajin batik semanggi kewalahan dengan jumlah pesanan yang besar. Akibatnya, beberapa kali pesanan dengan jumlah besar menjadi tidak dapat dikerjakan. Tentu ini menjadi kelemahan yang akan menghambat produksi batik semanggi.

2. Aspek kemampuan pemasaran online belum mumpuni. Pengrajin batik semanggi mengeluhkan keterbatasan mereka dalam memasarkan produk melalui online. Padahal, di era saat ini, peluang pemasaran melalui sistem online sangat besar.

3. Motif batik semanggi belum terdaftar sebagai hak kekayaan intelektual. Motif-motif batik semanggi yang khas ternyata belum terdaftar sebagai hak kekayaan intelektual. Tentu ini mengandung potensi permasalahn untuk masa yang akan datang jika motif tersebut belum terdaftarkan sebagai hak kekayaan intelektual karena rawan digunakan oleh pihak lain tanpa ijin.

4. Kapabilitas dalam pemasaran masih terbatas. Sistem pemasaran yang dibangun juga masih sangat terbatas. Mereka hanya menerima pesanan dari orang yang tahu akan adanya batik semanggi, tanpa ada upaya promosi yang lebih baik.

5. Keterbatasan dalam volume produksi, dikarenakan teknologi yang digunakan masih tradisional, biaya upgrade teknologi mahal, kuantitas SDM belum mencukupi. 


\section{Analisis Eksternal}

Seperti halnya analisis internal, analisis ekternal digunakan untuk menganalisis aspek positif dan negatif dalam peningkatan daya saing produk batik semanggi, namun dengan titik fokus yang berbeda. Jika analisis intenal berfokus pada internal kelompok pengrajin, maka analisis eksternal lebih bertumpu pada faktor-faktor yang berada di luar kelompok pengrajin. Analisis eksternal dilakukan untuk memetakan peluang dan hamatan. Peluang merupakan aspek yang bernilai positif (pendorong) bagi peningkatan daya saing produk batik semanggi, sedangkan ancaman merupakan aspek yang bernilai negatif (penghambat) bagi daya saing produk batik. Beikut ini peluang dan ancaman dalam produksi batik semanggi.

\section{Peluang}

1. Terdapat konsumen setia dari produk batik semanggi, sehingga tidak terpengaruh persaingan batik. Batik semanggi memiliki konsumen setia yang terdiri atas pegawai pemerintahan khususnya di kecamatan benowo, siswa di kecamatan benowo dan beberapa organisasi kemasyarakatan seperti Fatayat NU Surabaya.

2. Dibukanya peluang ekspor oleh pemerintah kota surabaya terhadap produk-produk lokal. Hal ini tentu menjadi peluang besar bagi batik semnaggi utuk merambah ke dunia ekspor.

3. Perhatian dari pemerintah kota surabaya terhadap batik semanggi melalui programprogram pelatihan, ajang pameran, dan bantuan-bantuang lainnya. Program-program ini tentu sangat penting untuk meningkatkan daya saing batik semanggi.

4. Adanya dukungan dari elemen kemasyarakatan lain seperti perhatian dunia perguruan tinggi dan organisasi kemasyarakatan dalam pengembangan batik semanggi. Dukungan tersebut seperti adanya pelatihan dan pesanan sebagai seragam.

5. Adanya peluang pemasaran via online sebagai bentuk perkembangan teknologi informasi dan komunikasi. Saat ini, peluang pemasaran online makin beragam dan berkembang sangat pesat. Ini tentu menjadi peluang yang sangat berharga untuk mendongkran pemasaran batik semanggi.

\section{Ancaman}

1. Munculnya pesaing batik khas/ikonik lain di Surabaya. Di surabaya mulai berkembang batik-batik khas yang lain. Tentu hal ini akan menjadi tantangan tersendiri bagi batik semnaggi untuk bersaing.

2. Munculnya usaha batik printing yang menawarkan produksi skala besar dan harga lebih murah. Terdapat beberapa jasa pembuatan batik printing dengan motif batik semanggi dengan harga yang ditawarkan jauh lebih murah dan skala produksi jauh lebih besar. Mereka mampu menawarkan harga yang lebih murah. Akibatnya, daya saing batik semnaggi menjadi berkurang dengan adanya batik printing tersebut.

3. Dibukanya JLLB akan menurunkan jumlah pengrajin akibat adanya relokasi beberapa rumah dari para pengrajin. Hal ini tentu akan mengurangi jumlah pengrajin, padahal selama ini kuantitas pengrajin dipandang belum mencukupi. Adanya relokasi akan Makin mengurangi jumlah pengrajin dan akan menurunkan daya produksi batik semanggi

TABLE 1 | Matriks SWOT

Peluang/ Opportunity 1. Terdapat konsumen setia 2.
Adanya peluang ekspor 3. Dukungan pemerintah tinggi 4.
Adanya dukungan dari elemen masyarakat lain 5. Adanya
perkembangan teknologi, informasi dan komunikasi
sehingga memungkinkan pemasaran online
Ancaman/Threat 1. Munculnya pesaing/batik dengan
motif lain khas surabaya 2. Munculnya batik printing yang
menawarkan harga jauh lebih murah dengan skala
produksi lebih besar 3. Adanya relokasi untuk JLLB yang
akan mengurani jumlah pengrajin.

Kekuatan/ Strenght 1. Kualitas SDM dalam membatik sudah mumpuni 2. Terdapat manajemen/tata kelola yang cukup baik 3. Motif khas yang ikonik 4. Teknologi batik organik

Kelemahan/ Weakness 1. Kuantitas SDM belum memadai 2. kemampuan pemasaran online belum mumpuni 3. Motif batik semanggi belum terdaftar sebaga hak kekayaan intelektual 4. Kapabilitas dalam pemasaran masih terbatas 5. Keterbatasan volume produksi 6 . Alat masih tradisional 7. Belum mampu upgrade teknologi karena belum ada modal

Dari matrik di atas, dapat diketahui bagaimana peta SWOT batik semanggi. Harapannya adalah dengan terpetakannya SWOT di atas akan dapat dirumuskan strategi pemberdayaan pengrajin batik semanggi Kelurahan Sememi Kecamatan Benowo Kota Surabaya yang komprehensif dan berkualitas. Peta SWOT tersebut amat berguna agar strategi yang dirumuskan 
dapat tepat sasaran, efisien, dan dapat menghindari tumpang tindih kebijakan.

\section{KESIMPULAN}

Batik semanggi memiliki beberapa kekuatan seperti kemampuan SDM dalam membatik, adanya manajemen sederhana yang handal, motif khas yang ikonik dan penggunaan teknologi organik, Sisi peluang antara lain adanya konsumen setia, peluang ekspor, dukungan pemerintah, dukungan organisasi kemasyarakatan, dan peluang pemasaran online.

Batik semanggi juga memiliki kelemahan antara lain kuantitas SDM kurang memadai, kemampuan pemasaran online rendah, motif batik belum terdaftar sebagai hak kekayaan intelektual, motif yang kurang variatif dan volume produksi yang sangat terbatas. Ancaman yang muncul antara lain adanya pesaing batik printing yang mampu memproduksi dengan skala lebih besar dan harga lebih rendah, adanya motif batik lain di Surabaya (pesaing), adanya pembangunan Jalur Lingkar Luar Barat Surabaya yang merelokasi beberapa pengrajin sehingga jumlah pengrajin semakin berkurang.

\section{UCAPAN TERIMA KASIH}

Penulis mengucapkan banyak terima Kasih kepada Civitas Akademika Universitas Pembangunan Nasional "Veteran" Jawa Timur atas segala dukungannya baik secara moril maupun materiil sehingga artikel ini dapat dipublikasikan di Jurnal Kebijakan dan Manajemen Publik Universitas Muhammadiyah Sidoarjo. Terima kasih juga kepada tim redaksi JKMP yang sudah menerima dan mempublikasikan naskah penelitian ini.

\section{REFERENCES}

David, F. R. (2014). Analisis SWOT Teknik Membedah Kasus Bisnis (Jakarta: Gramedia Pustaka Utama).

Juardi, M. and Djumadi, D. (2014). Pengembangan Usaha Industri Kecil Melalui Pemberdayaan Masyarakat di Kecamatan Tering Kabupaten Kutai Barat. Jurnal Administrative Reform 2.

Mardikanto, T. (2012). Pemberdayaan Masyarakat dalam Perspektif Kebijakan Publik (Bandung: Alfabeta).

Mayangsari, A. (2015). Dampak Pemberdayaan Pengrajin Batik Oleh Diskoperindag dan ESDM terhadap Peningkatan Kesejahteraan UMKM Batik Jetis Sidoarjo. Jurnal Kebijakan dan Manajemen Publik 3.

Miles, M. B. and Huberman, A. M. (1994). Qualitative Dato Analysis: An Expanded Sourcebook (California: SAGE Publication Inc).

Moleong (2012). Metodologi Penelitian Kualitatif (Bandung Rosda).

Sudantoko, D. (2011). Strategi Pemberdayaan Usaha Skala Kecil Batik di Pekalongan. Eksplanasi 6.
Suharto, E. (2005). Membangun Masyarakat Memberdayakan Rakyat: Kajian Strategis Pembangunan Kesejahteraan Sosial \& Pekerjaan sosial (Jakarta: PT. Refika Aditama).

Conflict of Interest Statement: The authors declare that the research was conducted in the absence of any commercial or financial relationships that could be construed as a potential conflict of interest.

Copyright (c) 2020 Hardjati, Prathama and Wahyudi. This is an open-access article distributed under the terms of the Creative Commons Attribution License (CC BY). The use, distribution or reproduction in other forums is permitted, provided the original author(s) and the copyright owner(s) are credited and that the original publication in this journal is cited, in accordance with accepted academic practice. No use, distribution or reproduction is permitted which does not comply with these terms. 